\title{
Age, Genetic Characteristics and Number of Cycles Are Critical Factors to Consider for Successful Protection of the Murine Heart With Postconditioning
}

\author{
S. J. SOMERS ${ }^{1}$, L. LACERDA ${ }^{1}$, L. OPIE $^{1}$, S. LECOUR $^{1}$ \\ ${ }^{1}$ Hatter Cardiovascular Research Institute, Department of Medicine, University of Cape Town, Cape \\ Town, South Africa
}

Received November 29, 2010

Accepted May 3, 2011

On-line October 12, 2011

\begin{abstract}
Summary
Postconditioning (PostC) is a recently discovered phenomenon whereby brief repetitive cycles of ischaemia with intermittent reperfusion following prolonged ischaemia elicit cardioprotection. This study investigated whether the age, genetic characteristics or number of repetitive cycles influenced the protective effect of PostC in mice. C57BL/6 floxed or non-floxed STAT-3 mice aged between 14-16 weeks (young) or 18-20 weeks (older) were perfused on a Langendorff apparatus and subjected to $35 \mathrm{~min}$ global ischaemia and 45 min reperfusion. PostC was elicited by either 3 (PostC-3) or 6 cycles (PostC- 6 ) of 10 s ischaemia and $10 \mathrm{~s}$ reperfusion. PostC- 3 and PostC- 6 in both young and older non-floxed mice reduced the myocardial infarct size. In contrast, only PostC-3 reduced myocardial infarct size in young floxed mice. Neither PostC-3 nor PostC- 6 reduced the infarct in older floxed mice. Our data reveal that genetic characteristics, a minute difference in age or the number of postconditioning cycles are critical factors to be considered for the successful effect of ischaemic postconditioning in a murine model. Moreover, these factors should be taken into consideration for future experimental research or clinical applications of this protective phenomenon.
\end{abstract}

\section{Key words}

Ischaemia • Reperfusion • Postconditioning

\section{Corresponding author}

S. J. Somers, Hatter Cardiovascular Research Institute, Private Bag X3, Observatory 7935, South Africa. Fax: +27214478789 . E-mail: sarin54@gmail.com
Ischaemic postconditioning is a phenomenon whereby brief alternating episodes of ischaemia/ reperfusion performed at the onset of reperfusion can limit the number of dead cells (Zhao et al. 2003). Ischaemic postconditioning was discovered initially in a dog model and very rapidly, its protective effect was also reported in rats, mice, rabbits and pigs (Kaljusto et al. 2006, Schwartz and Lagranha 2006, Skyschally et al. 2009).

Despite these promising results, the robustness of postconditioning across different animal species and models has yielded varying degrees of success and reproducibility. Using identical experimental conditions in two different laboratories, a group failed to explain why they could not successfully postcondition the isolated mouse heart in one of their laboratories (Kaljusto et al. 2006). Vinten-Johanssen's group successfully reduced infarct size in the canine model by 3 alternating cycles of occlusion and reperfusion (Zhao et al. 2003) but this same protocol did not protect in the pig model (Schwartz and Lagranha 2006).

Hence, in this paper, we propose to study the effect of age, genetic characteristics and number of cycles as critical factors to be considered for the success of ischaemic postconditioning in an in vitro mouse heart model.

\section{Isolated mouse heart model}

We compared the postconditioning effect in pure 
C57BL/6 mice with floxed mice from the same background. Floxed mice are animals that have a specific DNA sequence, Lox $\mathrm{P}$ (Locus of X-ing over P) site inserted and integrated into their germ line. Two Lox $\mathrm{P}$ sites have been inserted in the DNA sequence of STAT-3 (Signal Transducer and Activator of Transcription-3) such that these floxed mice may be bred with mice expressing the Cre Recombinase protein to produce a cardiomyocyte specific STAT-3 knockout (Smith et al. 2004). Mice aged between 14-16 weeks (younger) or 18-20 weeks (older), and weighing between 25-35 g, were anaesthetized before their hearts were excised and mounted on a Langendorff perfusion apparatus, as previously described (Smith et al. 2004). Only male mice were used in this study to rule out the protective influence of female sex hormones on postconditioning (Tissier et al. 2007).

Following $20 \mathrm{~min}$ of stabilization, the hearts were subjected to $35 \mathrm{~min}$ global ischaemia and $45 \mathrm{~min}$ reperfusion. Alternatively, hearts were postconditioned with either 3 or 6 cycles of $10 \mathrm{~s}$ ischaemia/reperfusion after the prolonged ischaemia. At the end of the experiments, hearts were stained with triphenyltetrazolium chloride and infarct size was calculated using computerized planimetry (Planimetry+, Boreal Software, Norway), as previously described (Smith et al. 2004).

\section{Statistics}

Data are expressed as mean values \pm S.E.M and were analysed by performing multiple group comparisons using one way ANOVA and followed by StudentNewman-Keuls post hoc test. A value of $\mathrm{p}<0.05$ was considered to be statistically significant. A minimum of 6 hearts were used per group.

To investigate the influence of age and number of cycles of postconditioning in C57BL/6 mice, 14-16 or 18-20 weeks old mouse hearts were postconditioned with either 3 or 6 cycles of $10 \mathrm{~s}$ ischaemia/reperfusion following the sustained ischaemia (Fig. 1). Ischaemic control hearts from younger and older adult had a comparable infarct size of $48.6 \pm 1.5 \%$ and $56.83 \pm 5.7 \%$, respectively. Application of 3 cycles of postconditioning (PostC-3) significantly reduced the ischaemic damage in younger mice $(14.2 \pm 0.9 \%)$ and to a lesser extent in older mice $(29.9 \pm 7.5 \%)$. Similarly, postconditioning with 6 cycles of ischaemia/reperfusion (PostC-6) also proved

\section{4-16 weeks}

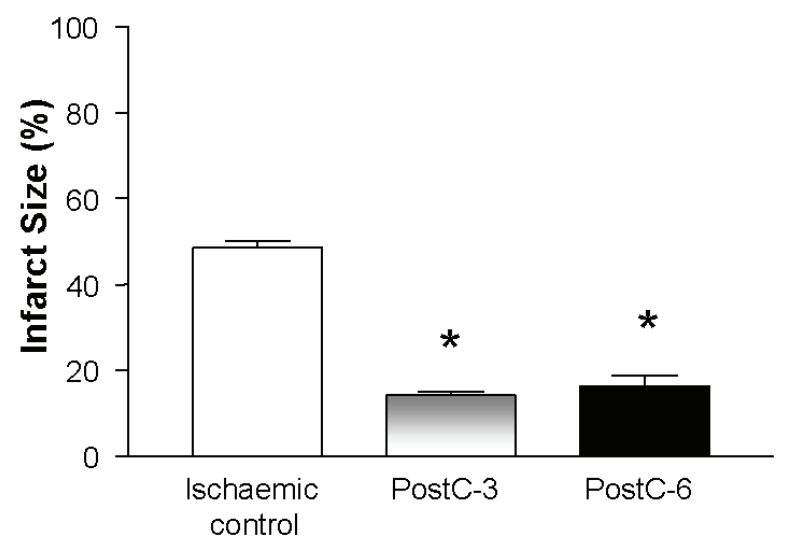

\section{8-20 weeks}

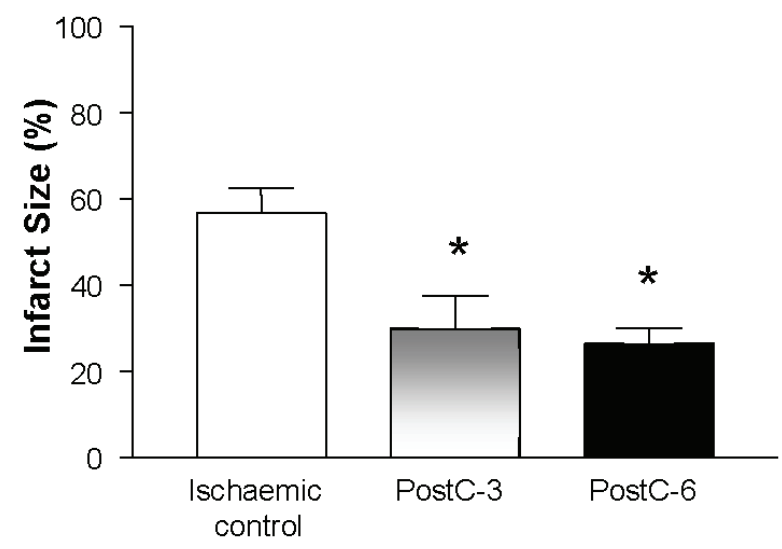

Fig. 1. Postconditioning improves infarct size in younger/older C57BL/6 non-floxed mice ( $n \geq 6 ; p<0.05$ vs control group).

to be beneficial in both the younger and older C57BL/6 mice (16.2 $\pm 2.6 \%$ and $26.4 \pm 3.6 \%$, respectively).

In floxed mice, ischaemic control hearts from younger animals had an infarct size of $51.2 \pm 4.2 \%$ (Fig. 2). Application of 3 cycles of postconditioning (PostC-3) significantly reduced the ischaemic damage in younger mice but not in older mice (infarct size of $26.2 \pm 5.3 \%$ in younger mice and $41.6 \pm 1.7 \%$ in older mice). Postconditioning with 6 cycles of ischaemia/ reperfusion (PostC-6) was not beneficial in either the younger and older floxed mice $(40.9 \pm 5.0 \%$ and $38.4 \pm 7.1 \%$, respectively vs $37.9 \pm 3.8 \%$ for control 


\section{4-16 weeks}

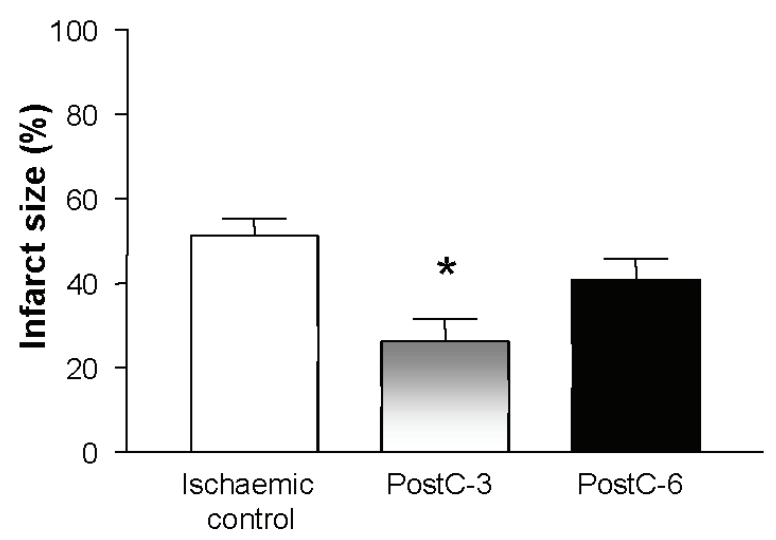

18-20 weeks

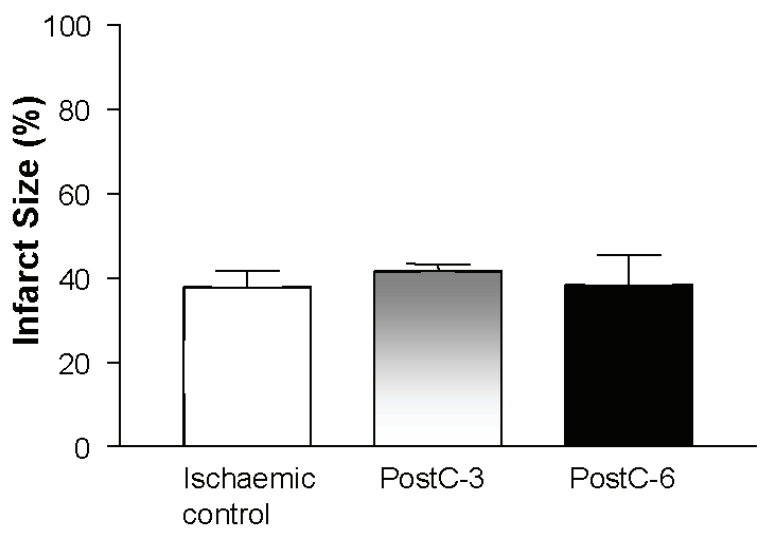

Fig. 2. Age and number of cycles influence the successful effect of postconditioning in floxed mice $(n \geq 6 ; p<0.05$ vs control group).

mice). The main finding is that the protective effect of PostC-6 was lost in older group of floxed mice. However, the control infarct size in this group $(37.9 \pm 3.8 \%)$ was smaller compared with the younger floxed group $(51.2 \pm 4.2 \%)$ or the older non-floxed group (56.8 $\pm 5.7 \%)$.

Our data provide important information to consider before establishing a postconditioning protocol in a mouse model. First, we were surprised to report that a minute difference in age of 2 weeks can affect the success of the ischaemic postconditioning effect. This loss of cardioprotection in mice has previously been observed with mice of 13 months of age (Boengler et al. 2008). Additionally, our data confirm how critical it is to select the proper control mice when working with genetic knockout animals as littermate floxed mice presented a different susceptibility to the postconditioning protocol compared with the corresponding pure C57BL6 mice.

The number of cycles used for a successful postconditioning effect varies amongst species. The protective effect of postconditioning was observed in the in vivo dog heart with $3 \times 30 \mathrm{~s}$ cycles of reperfusion and ischaemia (Zhao et al. 2003). In a mouse model, 3x10 s, $6 \times 10 \mathrm{~s}$ or $5 \times 5 \mathrm{~s}$ can protect the in vivo heart against reperfusion injury (Boengler et al. 2008, Lacerda et al. 2009). Using the isolated mouse heart model, algorithms of 10x5 s (C57Black6xBalb/c strain), 3x5 s and 6x10 s (C57/Black6 strain) were proved to be protective (Nishino et al. 2008, $\mathrm{Xi}$ et al. 2008). Using the C57/Black6 strain, our data showed that both $3 \times 10 \mathrm{~s}$ and $6 \times 10 \mathrm{~s}$ cycles of ischaemia/reperfusion could reduce the infarct to a similar extent.

However, we observed that floxed mice could be postconditioned with $3 \times 10 \mathrm{~s}$ cycles but failed to be protected with $6 \times 10$ s. An insertion of 2 loxP gene fragments into the MLC2V targeted gene is usually thought to be silenced but may influence the successful effect of postconditioning. STAT-3 is a transcription factor that is essential in mediating the cardioprotective effect of ischaemic postconditioning (Boengler et al. 2008, Lacerda et al. 2009). However, abnormal alterations in STAT-3 levels have shown to be detrimental to the heart. The lack of cardiac STAT-3 lead to dilated cardiomyopathy and overstimulation of STAT-3 caused inflammation, adverse remodeling and heart failure (Hilfiker-Kleiner et al. 2004, 2010). Although never described in the literature, STAT-3 may have a critical role in the development process of the heart, which the insertion of lox $\mathrm{P}$ may interfere with at 16-18 weeks. An effect of lox $\mathrm{P}$ has previously been reported with hyperandrogenization in male mice containing a floxed allele of the androgen receptor gene (MacLean et al. 2008).

In our study, we report that a minor age difference in floxed mice from 14-16 weeks to 18-20 weeks can negatively affect the outcome of postconditioning. This was in contrast with the hearts from genetically unmodified C57BL/6 mice which were still able to be postconditioned at 18-20 weeks. It would be of interest to explore protective effect of these mice at an older age.

Our data strongly suggest that the genetic characteristics of the mouse, age and number of postconditioning cycles are critical factors to be considered in ischaemic postconditioning. Different 
animal models may require different postconditioning protocols. It might be possible that the discrepancies observed in the floxed mice may be due to the dysregulation of gene programs that affect the postconditioning effect. These factors should be taken into consideration for future experimental research or clinical applications of this protective phenomenon.

\section{Conflict of Interest}

There is no conflict of interest.

\section{Acknowledgements}

This work was supported by the National Research Foundation and the South African Medical Research Council. Sarin J. Somers was supported by Jan Minners Scholarship.

\section{References}

BOENGLER K, BUECHERT A, HEINEN Y, ROESKES C, HILFIKER-KLEINER D, HEUSCH G, SCHULZ R: Cardioprotection by ischemic postconditioning is lost in aged and STAT3-deficient mice. Circ Res 102: 131$135,2008$.

HILFIKER-KLEINER D, HILFIKER A, FUCHS M, KAMINSKI K, SCHAEFER A, SCHIEFFER B, HILLMER A, SCHMIEDL A, DING Z, PODEWSKI E, POLI V, SCHNEIDER MD, SCHULZ R, PARK JK, WOLLERT KC, DREXLER H: Signal transducer and activator of transcription 3 is required for myocardial capillary growth, control of interstitial matrix deposition, and heart protection from ischemic injury. Circ Res 95: $187-$ 195, 2004.

HILFIKER-KLEINER D, SHUKLA P, KLEIN G, SCHAEFER A, STAPEL B, HOCH M, MULLER W, SCHERR M, THEILMEIER G, ERNST M, HILFIKER A, DREXLER H: Continuous glycoprotein-130-mediated signal transducer and activator of transcription-3 activation promotes inflammation, left ventricular rupture, and adverse outcome in subacute myocardial infarction. Circulation 122: 145-155, 2010.

KALJUSTO ML, MORI T, MOHAMMAD HUSAIN RIZVI S, GALAGUDZA M, FRANTZEN ML, VALEN G, VAAGE J: Postconditioning in rats and mice. Scand Cardiovasc J 40: 334-341, 2006.

LACERDA L, SOMERS S, OPIE LH, LECOUR S: Ischaemic postconditioning protects against reperfusion injury via the SAFE pathway. Cardiovasc Res 84: 201-208, 2009.

MACLEAN HE, CHIU WS, MA C, MCMANUS JF, DAVEY RA, CAMERON R, NOTINI AJ, ZAJAC JD: A floxed allele of the androgen receptor gene causes hyperandrogenization in male mice. Physiol Genomics 33: 133$137,2008$.

NISHINO Y, WEBB IG, DAVIDSON SM, AHMED AI, CLARK JE, JACQUET S, SHAH AM, MIURA T, YELLON DM, AVKIRAN M, MARBER MS: Glycogen synthase kinase-3 inactivation is not required for ischemic preconditioning or postconditioning in the mouse. Circ Res 103: 307-314, 2008.

SCHWARTZ LM, LAGRANHA CJ: Ischemic postconditioning during reperfusion activates Akt and ERK without protecting against lethal myocardial ischemia-reperfusion injury in pigs. Am J Physiol Heart Circ Physiol 290: H1011-H1018, 2006.

SKYSCHALLY A, VAN CASTER P, BOENGLER K, GRES P, MUSIOLIK J, SCHILAWA D, SCHULZ R, HEUSCH G: Ischemic postconditioning in pigs: no causal role for RISK activation. Circ Res 104: 15-18, 2009.

SMITH RM, SULEMAN N, LACERDA L, OPIE LH, AKIRA S, CHIEN KR, SACK MN: Genetic depletion of cardiac myocyte STAT-3 abolishes classical preconditioning. Cardiovasc Res 63: 611-616, 2004.

TISSIER R, WAINTRAUB X, COUVREUR N, GERVAIS M, BRUNEVAL P, MANDET C, ZINI R, ENRIQUEZ B, BERDEAUX A, GHALEH B: Pharmacological postconditioning with the phytoestrogen genistein. $\mathrm{J}$ Mol Cell Cardiol 42: 79-87, 2007.

XI L, DAS A, ZHAO ZQ, MERINO VF, BADER M, KUKREJA RC: Loss of myocardial ischemic postconditioning in adenosine A1 and bradykinin B2 receptors gene knockout mice. Circulation 118: S32-S37, 2008.

ZHAO ZQ, CORVERA JS, HALKOS ME, KERENDI F, WANG NP, GUYTON RA, VINTEN-JOHANSEN J: Inhibition of myocardial injury by ischemic postconditioning during reperfusion: comparison with ischemic preconditioning. Am J Physiol Heart Circ Physiol 285: H579-H588, 2003. 